\title{
The chemistry and bioactivity of various heartwood extracts from redwood (Sequoia sempervirens) against two species of fungi
}

\author{
Nicholas Tuatahi Davies, Hsin-Fu Wu and Clemens Michael Altaner*
}

\begin{abstract}
Background: Sequoia sempervirens (D. Don) Endl.) (redwood) has the potential to be grown in New Zealand in commercial forestry operations and is valued for its naturally durable heartwood. A viable redwood industry based on planted forests can only be achieved if the timber produced meets quality expectations, in particular durability. Natural durability is highly variable among trees. Also, a within-tree pattern of low durability close to the pith has been observed. Natural durability is preliminarily caused by secondary metabolites deposited into the cell walls during heartwood formation. The exact nature of the compounds responsible for natural durability in redwood is unknown.

Methods: Samples of heartwood from 22 different trees were obtained, ground and extracted using a range of solvents. The ability of some of these extracts to reduce the growth of two fungi (Gloeophyllum trabeum and Trametes versicolor) was tested in vitro. Information on the composition of the extracts was obtained using infrared spectroscopy and gas chromatography.

Results: Fungicidal properties were found in solvent extracts of ground S. sempervirens heartwood samples at concentrations comparable to those known to be present in intact wood. The entire acetone-soluble extracts and ethyl-acetate-soluble fraction of the ethanol extracts caused the greatest reduction in the growth of both fungi tested. Large variations in acetone-soluble or ethanol-soluble extract content and fungicidal activity among trees were found. Agatharesinol and sequerin-C appear to be trace compounds in the dried extracts of S. sempervirens.
\end{abstract}

Conclusions: Further work is needed to identify the key compounds contributing to the natural durability of S. sempervirens.

Keywords: Sequoia sempervirens; Redwood; Natural durability; Extractives; Gloeophyllum trabeum; Trametes versicolor

\section{Background}

The timber of Sequoia sempervirens (D. Don) Endl. (redwood) is widely used and highly valued for its natural durability, attractive colour, dimensional stability and low density (Cornell 2002; Cown et al. 2013). Supply of redwood timber from natural forests is dwindling and classed vulnerable by the International Union for Conservation of Nature (ICUN) (Farjon et al. 2006). Growing redwoods in planted forest to substitute this resource has the potential to be a highly profitable business in New Zealand, which is helped by the fast growth rates of this species (Cornell 2002; Palmer et al. 2012). A

\footnotetext{
* Correspondence: clemens.altaner@canterbury.ac.nz

New Zealand School of Forestry, University of Canterbury, Christchurch, New Zealand
}

key requirement for establishing a redwood industry based on planted forests is to ensure a consistent high quality of the produced timber (Cown 2008; Cown et al. 2013). This is especially true for wood from young trees as the desired properties usually improve with tree age (Walker 2006). The natural durability of redwood timber has been reported to be highly variable, ranging from very durable to moderately/non-durable (Clark and Scheffer 1983; Scheffer and Morell 1998; Jones et al. 2011). Variation in natural durability exists among trees (due to genetic and environmental factors) as well as within trees (mainly associated with cambial age).

The natural durability of timber has been largely attributed to the deposition of low molecular weight secondary metabolites into the wood during heartwood 
formation (Hillis 1987; Taylor et al. 2002). The deposited secondary metabolites are also known as heartwood extractives as they can be extracted by various solvents from the heartwood. Extractives are comprised of numerous organic compounds of which some possess fungicidal, bactericidal or insecticidal properties (Rowe 1989).

Despite the importance of natural durability to the product and the size of the redwood industry surprisingly little is known of the molecular basis for its natural durability, i.e. the extractive compounds responsible.

This article (a) reviews the existing literature regarding the natural durability of $S$. sempervirens heartwood and the extractives compounds in this material and (b) provides some experimental data on the quantity and bioactivity of various $S$. sempervirens extracts and their variability.

\section{Literature review}

\section{Natural durability}

The natural durability of Sequoia sempervirens heartwood has been assessed in various ways over the years (Table 1). It is interesting to note that some reports indicate that redwood timber is less durable in moist soils (Hedley and Foster 1972; Johnson et al. 1996) or climates (Eslyn et al. 1985; Highley 1995). This suggests that either water-soluble extracts play a prominent role for the natural durability of this timber or that the fungi present in those environments are more tolerant to the extractives present in S. sempervirens heartwood. Furthermore, high variability of natural durability can be found among and within trees.

\section{Variability among trees}

Wilcox and Piirto (1976) found a 15-fold variation in weight loss among redwood heartwood samples of the widest possible naturally occurring range of colour intensity. These samples contained wood from old-growth trees and second-growth trees. Their findings were consistent with the large variability in natural durability reported for plantation-grown redwood from New Zealand (Jones et al. 2011, 2014). Heartwood durability according to Standard EN350-1 (CEN 1994) varied from 'notdurable' to 'very-durable', with the majority of samples being 'durable' or 'very-durable'. Also, variable resistance against termite attack has been reported for redwood heartwood sourced from different regions in the USA (Grace and Yamamoto 1994).

\section{Variability within trees}

Sherrard and Kurth (1933a) analysed the variation in natural durability within a single redwood stem using a range of decay tests conducted either under field or laboratory conditions. Natural durability significantly increased from pith to bark and slightly from bottom to top in the heartwood of the stem. These radial and axial gradients in natural durability were confirmed for oldgrowth and second-growth trees $(<100$ years) (Clark and Scheffer 1983), and are consistent with the data reported for plantation-grown redwood from New Zealand (Jones et al. 2011, 2014). Gradients in natural durability have also been observed in other species (Taylor et al. 2002) and highlight the general inferior wood quality of corewood, the wood formed by cambium of young age (Burdon et al. 2004).

\section{Extractive content}

Extractive content and its variability in S. sempervirens wood has been investigated previously by various researchers (Table 2). Different classes of compounds are extracted by different solvents depending on their solubility. The total amount of extractives is difficult to ascertain as it requires sequential extractions with various solvents (Tappi 1988).

The amount of heartwood extract varies greatly among trees, with younger trees generally having lower quantities than older trees (Sherrard and Kurth 1933a; Anderson 1961; Resch and Arganbright 1968; Kuo and Arganbright 1980). Within stems radial and axial gradients in heartwood extracts follow the natural durability pattern indicating that young trees are less active in metabolising extractives. Additionally, reports of extremely low extractive contents next to the pith for very old $S$. sempervirens trees $(600+$ years) suggest a slow degradation of extracts (Resch and Arganbright 1968).

\section{Bioactivity of S. sempervirens heartwood extracts}

Although extractive compounds are likely to be responsible for improving natural durability, it is unclear how active individual compounds of $S$. sempervirens heartwood are against individual wood decaying fungi. Some work in the past century has attempted to identify various active compounds by investigating the toxicity of fractions of the heartwood extractives against various fungi.

The fungicidal activity of water extracts has been found to vary with fungal species. Cold-water extracts were found to retard the growth of the white-rot fungus Heterobasidion annosum (Fr.) Bref. and hot-water extracts were even more inhibiting (Hawley et al. 1924; Sherrard and Kurth 1933a). Cold-water extracts also inhibited the growth of the brown-rot fungi Postia placenta (Fr.) M. J. Larsen \& Lombard, Neolentinus lepideus (Fr.) Redhead \& Ginns and Gloeophyllum trabeum (Pers.) Murrill although hot-water extracts did not (Anderson et al. 1962). Interestingly, water extracts from sapwood showed some activity against Heterobasidion annosum (Hawley et al. 1924). The water-insoluble compounds from an acetone extract (largely phlobaphenes) did not affect growth of Postia 
Table 1 Published studies assessing the natural durability of Sequoia sempervirens timber

\begin{tabular}{|c|c|c|c|}
\hline $\begin{array}{l}\text { Test type (number and name of species in } \\
\text { brackets, if known) }\end{array}$ & Classification & $\begin{array}{l}\text { Origin of timber } \\
\text { (type of wood in brackets) }\end{array}$ & Reference \\
\hline Field test & Non-durable & unknown & Hedley and Foster 1972 \\
\hline $\begin{array}{l}\text { Laboratory test (ASTM 2005) (5 brown-rot } \\
\text { fungi (Gloeophyllum trabeum, Coniophora } \\
\text { olivacea (Fr.) P. Karst., Postia placenta and } \\
2 \text { unidentified isolates) and } 5 \text { white-rot } \\
\text { fungi (Fuscoporia gilva (Schwein.) T. Wagner } \\
\& \text { M. Fisch., Pycnoporus coccineus (Fr.) } \\
\text { Bondartsev \& Singer, Trametes versicolor } \\
\text { and } 2 \text { unidentified isolates)) }\end{array}$ & Moderately resistant & unknown & Hedley and Foster 1972 \\
\hline $\begin{array}{l}\text { Modified laboratory test (buried) (5 brown-rot } \\
\text { fungi (Gloeophyllum trabeum, Coniophora } \\
\text { olivacea, Postia placenta and } 2 \text { unidentified } \\
\text { isolates) and } 5 \text { white-rot fungi (Fuscoporia } \\
\text { gilva, Pycnoporus versicolor, Trametes versicolor } \\
\text { and } 2 \text { unidentified isolates)) }\end{array}$ & Non-resistant & unknown & Hedley and Foster 1972 \\
\hline $\begin{array}{l}\text { Laboratory ( } 2 \text { brown-rot fungi (Gloeophyllum } \\
\text { trabeum, Postia placenta)) }\end{array}$ & Weight-loss of $18-45 \%$ & $\begin{array}{l}\text { unknown origin (sawmill boards } \\
\text { of widest possible natural range) }\end{array}$ & Wilcox and Piirto 1976 \\
\hline $\begin{array}{l}\text { Laboratory ( } 16 \text { soft-, brown- and } \\
\text { white-rot fungi) }\end{array}$ & $\begin{array}{l}\text { Very resistant against soft-rot, resistant } \\
\text { against white-rots and moderately } \\
\text { resistant against brown-rots }\end{array}$ & unknown origin (sapwood) & Eslyn and Highley 1976 \\
\hline $\begin{array}{l}\text { Laboratory ( } 2 \text { brown-rot fungi (Gloeophyllum } \\
\text { trabeum and Postia placenta)) }\end{array}$ & Very to moderately resistant & $\begin{array}{l}\text { California (outer third heartwood } \\
\text { of the top of the butt-log) }\end{array}$ & Clark and Scheffer 1983 \\
\hline Field tests (above ground) & $\begin{array}{l}\text { Sapwood: } 15 \text { years in moist and } \\
25 \text { years in dry climates; heartwood: } \\
>20 \text { years in moist and } 30 \text { years in } \\
\text { dry climates }\end{array}$ & $\begin{array}{l}\text { unknown origin (sapwood and } \\
\text { heartwood) }\end{array}$ & $\begin{array}{l}\text { Eslyn et al. 1985; } \\
\text { Highley } 1995\end{array}$ \\
\hline Field test & Durable & unknown & Miller 1986 \\
\hline Laboratory test (11 soft-rot fungi) & $\begin{array}{l}\text { Little weight loss compared to } \\
\text { Pinus ponderosa }\end{array}$ & unknown origin (heartwood) & Morrell and Smith 1988 \\
\hline $\begin{array}{l}\text { Laboratory using termites (Coptotermes } \\
\text { formosanus Shiraki) }\end{array}$ & Termite resistance & $\begin{array}{l}\text { California and Oregon (Top-grade } \\
\text { glulam stock) }\end{array}$ & Grace and Yamamoto 1994 \\
\hline Field test & $\begin{array}{l}\text { Durable in dry site; Non-durable in } \\
\text { wet-sites }\end{array}$ & unknown & Johnson et al. 1996 \\
\hline $\begin{array}{l}\text { Laboratory ( } 2 \text { brown-rot fungi (Coniophora } \\
\text { puteana (Schumach.) P. Karst., Gloeophyllum } \\
\text { trabeum) and } 1 \text { white-rot fungus } \\
\text { (Trametes versicolor)) }\end{array}$ & $\begin{array}{l}\text { Large variation from very-durable (1) } \\
\text { to not-durable (5). Site averages (2)-(4) } \\
\text { (increasing resistance with age) }\end{array}$ & $\begin{array}{l}\text { New Zealand }(22,38 \text { and } \\
71 \text { years old) }\end{array}$ & Jones et al. 2011 \\
\hline
\end{tabular}

placenta, Neolentinus lepideus and Gloeophyllum trabeum (Anderson et al. 1962). An ethyl acetate extract did not show any activity against Phytophthora ramorum Werres, De Cock \& Man in 't Veld (Manter et al. 2007). Cabrera (2008) found no bioactivity from hexane, dichloromethane or ethanol extracts on Postia placenta and Trametes versicolor (L.) Lloyd when tested at concentrations as high as 24,000 ppm. Wood extracted with hot-water lost most of its resistance against decay by Postia placenta and also exhibited partly reduced resistance against decay by Neolentinus lepideus and Gloeophyllum trabeum (Anderson et al. 1962). Acetone extraction slightly reduced the natural durability against Postia placenta but this was not attributed to the removed extractives but rather the higher temperatures to which the wood was exposed for solvent removal
(Anderson et al. 1962). The durability of S. sempervirens heartwood against Postia placenta and Gloeophyllum trabeum was correlated with the amount of matter present in the ethanol extracts after hot-water extraction while no correlation was found for the hot-water extractable material (Wilcox and Piirto 1976).

\section{Chemical nature of heartwood extracts in S. sempervirens}

The structures of individual compounds found in heartwood of S. sempervirens trees are largely unknown. Some studies report the structures of compounds isolated from small twigs that likely do not contain heartwood but a mixture of leaves, bark and sapwood (Gadek and Quinn 1989; Zhang et al. 2004; Zhang et al. 2005). Others analysed isolated leaves (as summarised by Erdtman and Norin 1966), cones (Kritchevsky and Anderson 1955) or bark 


\begin{tabular}{|c|c|c|}
\hline Solvent & $\begin{array}{l}\text { Extractive } \\
\text { content (\%) }\end{array}$ & Reference \\
\hline \multirow[t]{6}{*}{ Hot water extract } & 10.5 & Hawley et al. 1924 \\
\hline & $5.5-28.2$ & Sherrard and Kurth 1933b \\
\hline & $8-10$ & Resch and Arganbright 1968 \\
\hline & $3.9-12.7$ & Wilcox and Piirto 1976 \\
\hline & $12.3-26.3$ & Kuo and Arganbright 1980 \\
\hline & 9.9 & Hillis 1987 \\
\hline \multirow[t]{4}{*}{ Cold water extract } & 14.4 & Hawley et al. 1924 \\
\hline & $10.5-18.3$ & Anderson et al. 1960 \\
\hline & $5.8-16.2$ & Anderson et al. 1962 \\
\hline & $7-16$ & Demaree and Erickson 1975 \\
\hline Ethanol & $3.1-5$ & Cabrera 2008 \\
\hline \multirow[t]{3}{*}{ Hot ethanol (after hot water) } & $1.4-8.1$ & Wilcox and Piirto 1976 \\
\hline & $1-2$ & Resch and Arganbright 1968 \\
\hline & $3.0-6.9$ & Kuo and Arganbright 1980 \\
\hline \multirow[t]{2}{*}{ Hot ethanol (after cold water) } & 7.2-12.7 & Anderson et al. 1960 \\
\hline & 7.8-14.9 & Anderson et al. 1962 \\
\hline Ether & 1.1 & Hillis 1987 \\
\hline $0.5 \% \mathrm{NaOH}$ & 20 & Hillis 1987 \\
\hline \multirow[t]{2}{*}{ Acetone } & 13.5 & Buchanan et al. 1944 \\
\hline & Approx. 3.2 & Anderson et al. 1962 \\
\hline Hexane & $0.1-0.3$ & Cabrera 2008 \\
\hline Dichloromethane & $1.8-2.0$ & Cabrera 2008 \\
\hline
\end{tabular}

(Lewis et al. 1944). The extracts in these plant tissues are known to differ greatly (Anderson 1961). Therefore, it is unclear if any of these reported compounds are present in heartwood.

Early analyses of $S$. sempervirens heartwood extracts quantified several broad classes of compounds. The composition of a typical water extract of green S. sempervirens heartwood was summarised by Anderson (1961). The major compounds were condensed tannins (Buchanan et al. 1944), several cyclitols (Anderson et al. 1968) and unidentified polyphenolics. Other unspecified components, carbohydrates (mainly arabinose) (Smith and Zavarin 1960) and colouring matter (Sherrard and Kurth 1933b) are present as minor compounds. The composition of a typical water-insoluble heartwood extract was reported to consist of about three quarters phlobaphenes and the remaining quarter contained similar amounts of native lignin, phenolics, fatty acids, waxes and neutrals (Anderson 1961).

Several norlignans have been isolated from S. sempervirens heartwood (as summarised by Rowe 1989). These include sugiresinol (also known as sequerin-A) (Sherrard and Kurth 1933b; Balogh and Anderson 1965), hydroxysugiresinol (also known as sequerin-B), sequerin- $\mathrm{C}$ (also known as sequerin) (Hatam and Whiting 1969; Riffer and Anderson 1967), sequerin-D (Begley et al. 1973), yateresinol (Erdtman and Harmatha 1979) and probably agatharesinol (Henley-Smith and Whiting 1976; Rowe 1989; Castro et al. 1996). Methyl anisate, anisaldehyde, and p-dimethoxybenzene were also listed by Henley-Smith and Whiting (1976).

\section{Chemical reactions of $S$. sempervirens heartwood extracts}

Biosynthesis of norlignans differs from that of lignans (Suzuki and Umezawa 2007; Yoshida et al. 2006). There is evidence that the conversion of agatharesinol into sequerin-C involves enzymes (Imai et al. 2009) but an abiotic conversion mechanism has also been proposed (Erdtman and Harmatha 1979). These norlignans have also been proposed to be a precursor of tannins/phlobaphenes in S. sempervirens which polymerise by enzymeor acid-catalysis (Erdtman and Harmatha 1979). Norlignans, in particular agatharesinol and sequerin- $C$, have been connected to the natural durability of Cryptomeria japonica (L. f.) D. Don heartwood (Ohtani et al. 2009). C. japonica is a species related to S. sempervirens (Gadek et al. 2000; Christenhusz et al. 2011). The role of norlignans in the natural durability of $S$. sempervirens has been suggested by Balogh and Anderson (1965) but not considered in subsequent studies (e.g. Piirto and Wilcox 1981). The bioactivities of norlignans (Suzuki and Umezawa 2007) and lignans (MacRae and Towers 1984) have been reviewed.

The influence of drying on the natural durability of redwood has been investigated in various studies (Anderson et al. 1960; Scheffer and Eslyn 1961; Anderson et al. 1962). Temperatures above $77^{\circ} \mathrm{C}$ (as well as pre-steaming and solvent drying) reduced the natural durability of redwood timber. The oxidation of heartwood compounds was found to be a contributing factor. Reduced resistance against the brown-rot fungus Fomitopsis palustris (Berk. \& M. A. Curtis) Gilb. \& Ryvarden and termites following high temperature drying were also reported for $C$. japonica. The decrease in termite resistance was attributed to a loss in agatharesinol and sequerin- $\mathrm{C}$ (summarised by Matsushita et al. 2008).

Redwood heartwood is pale in the freshly felled green state and changes colour when exposed to the atmosphere (e.g. Sherrard and Kurth 1933b; Balogh and Anderson 1965). A similar phenomenon is observed in the heartwood of $C$. japonica where the observed colour change has been related to the present norlignans, which change colour upon air-oxidation (with the exception of agatharesinol and sugiresinol) (Takahashi and Mori 2006). Discolouration of the heartwood of S. sempervirens can also occur (Ellwood et al. 1960). It has been related to the presence of sequerin-C (Balogh and Anderson 1965) and is 
facilitated by partial oxygen pressure, (low) $\mathrm{pH}$, temperature and heavy metals (Zavarin and Smith 1962).

\section{Materials and methods Materials}

Samples for assessing the effects of different solvents on extractive recovery and their composition were obtained from the inner five annual rings of heartwood from a single 17-year-old Sequoia sempervirens tree (Tree A). This tree was located on the North Island, New Zealand and sampled at breast height.

Samples for assessing the variability of heartwood extracts were obtained from a further 21 different US or New Zealand grown S. sempervirens trees (Trees B-V). Heartwood was collected at breast height from the inner seven year rings.

All samples were milled to pass a $2 \mathrm{~mm}$ screen and stored in a desiccator over dry silica gel prior to use.

The brown-rot fungus Gloeophyllum trabeum (ICMP 13887) and the white-rot fungus Trametes versicolor (ICMP 18215) were obtained from the International Collection of Micro-organisms from Plants (Landcare Research, New Zealand). These fungi are used in international standards (e.g. CEN 1994, Australian Wood Preservation Committee 2007) for assessing the natural durability of wood. Solvents (water, ethanol, acetone, ethyl acetate or dichloromethane (DCM)) used for the extraction of wood were of HPLC grade. Fungal growth was assessed using a base of malt-extract agar (Merck) containing $30.0 \mathrm{~g} \mathrm{~L}^{-1}$ malt extract, $3.0 \mathrm{~g} \mathrm{~L}^{-1}$ soymeal peptone and $15 \mathrm{~g} \mathrm{~L}^{-1}$ agar.

\section{Methods}

Extractions: S. sempervirens heartwood was extracted using an Accelerated Solvent Extractor (Thermo) equipped with $33 \mathrm{~mL}$ cells. In each run $7.2 \mathrm{~g}$ of dry milled heartwood (accurately weighed) was extracted. The extraction conditions were two cycles at $70^{\circ} \mathrm{C}$ for 15 min (static time) followed by a rinse using $50 \%$ of the cell volume, resulting in approx. $70 \mathrm{~mL}$ of extract. Extractions for the bioactivity of the extracts were performed in duplicate. The limited amount of material from Trees B$\mathrm{V}$ did not allow replication of the extractions of the 21 samples used for the variability tests. Extractive content was measured gravimetrically after drying at $105^{\circ} \mathrm{C}$ using a third of each extract. The ethyl acetate soluble fraction of the ethanol extract $(\mathrm{EtOH} \rightarrow$ EtAc) was obtained by removing the ethanol in a vacuum rotary evaporator then re-dissolving the residue in ethyl acetate and shaking overnight; the non-soluble fraction was removed by filtration. The remaining two thirds of each extract were used directly for the fungal assay described below.

Fourier Transform-Infrared (FT-IR) spectroscopy: Spectra of the dried portion of each extract were taken in duplicate with a Tensor 37 spectrometer (Bruker) using the Attenuated Total Reflectance (ATR) sampling technique. Each spectrum was composed of 32 scans. No qualitative difference between the replicates of each extract was found so the four spectra (two replicate FT-IR measurements of two extractions per solvent) were averaged. Spectra were normalised to the aromatic signal at $1510 \mathrm{~cm}^{-1}$.

Gas chromatography (GC): Air dried extracts were dissolved in pyridine at a concentration of approximately $100 \mathrm{~g} \mathrm{~L}^{-1}$. A $15 \mu \mathrm{L}$ aliquot of each solution was trimethylsilylated at room temperature using $50 \mu \mathrm{L}$ of $\mathrm{N}$, O-bis(trimethylsilyl)-trifluoroacetamide (BSTFA, SigmaAldrich) in a septum-sealed vial for 20 min according to the supplier's recommendations. The trimethylsilyl derivatives were analysed by GC on a CP-3800 (Varian) chromatograph fitted with a fused-silica capillary column $\left(30 \mathrm{~m} \times 0.25 \mathrm{~mm} /\right.$ Equity $\left.^{\circ}-1\right)$ using helium as the carrier gas $\left(1.2 \mathrm{~mL} \mathrm{~min}^{-1}\right)$ and FID detection at $300^{\circ} \mathrm{C}$. The initial oven temperature was set to $116^{\circ} \mathrm{C}$, ramped up to $280^{\circ} \mathrm{C}$ at $10^{\circ} \mathrm{C} \mathrm{min}{ }^{-1}$ and held for $40 \mathrm{~min}$. Sequerin-C and agatharesinol (isolated from Metasequoia glyptostroboides $\mathrm{Hu} \&$ Cheng by ChemFaces Biochemical Co., Wuhan, P.R.C) were used as reference materials.

Fungal assays: Malt agar gels $(4.8 \% \mathrm{w} / \mathrm{v})$ containing the remaining extract (i.e. from $4.8 \mathrm{~g}$ of dry wood) were prepared so that the amount of extract in each gel corresponded to the extractive content of the wood sample. Each extract solution $(\sim 50 \mathrm{~mL})$ was added to $100 \mathrm{~mL}$ of distilled water. Each solution was placed in a water bath $\left(80^{\circ} \mathrm{C}\right)$ until no solvent odour was noticeable to remove fungicidal effects of the extraction solvent. This step took approximately $6 \mathrm{~h}$. Care was taken to prevent the extracts from drying. Any loss of water due to evaporation was corrected by making the final volume up to $100 \mathrm{~mL}$ with distilled water. Malt agar $(4.8 \mathrm{~g})$ was added and the solution was autoclaved $\left(121^{\circ} \mathrm{C}, 10 \mathrm{~min}\right)$ and poured into $50 \mathrm{~mm}$ diameter petri dishes (five petri dishes for each extract and each fungus). Solvent controls containing the equivalent amount of solvent but no extractives underwent the same procedures as the malt agars containing wood extracts. Plates were allowed to cool. After gelation, a small amount of fungus was placed in the centre of each petri dish. Fungi were grown at $25^{\circ} \mathrm{C}$. Two perpendicular diameters of the fungus in each petri dish were measured approximately every $24 \mathrm{~h}$ over the course of a week using a pair of digital callipers. The absolute growth rate $\left(\mathrm{mm} \mathrm{h}^{-1}\right)$ was calculated by fitting a linear regression for the averaged diameter against time for each petri dish. The experiment was duplicated for testing different solvent extracts but only a single extraction was possible due to the small sample size when assessing the variability of the extracts in 21 separate tree samples. 
Table 3 Yield of extract from the inner five annual heartwood rings from Tree $A$ and the inner seven annual heartwood rings from Trees B-V. Given values are the averages of duplicate extractions

\begin{tabular}{lcc}
\hline Solvent & \multicolumn{2}{c}{ Extract (\%) of dry wood } \\
\cline { 2 - 3 } & $\begin{array}{l}\text { Inner heartwood } \\
\text { of Tree A }\end{array}$ & $\begin{array}{l}\text { Heartwood of Trees B } \\
\text { to V; min - max. } \\
\text { (mean in brackets) }\end{array}$ \\
\hline Water & 5.2 & $5.4-12.8(8.9)$ \\
Ethanol & 6.4 & $1.4-5.1(2.6)$ \\
Ethanol $\rightarrow$ Ethyl acetate & 3.5 & \\
Acetone & 3.7 & \\
Ethyl acetate & 1.4 & \\
Dichloromethane & 0.6 & \\
\hline
\end{tabular}

${ }^{1}$ Ethanol $\rightarrow$ Ethyl acetate: ethyl acetate soluble fraction of the ethanol extract.

Statistics: Solvent controls showed that potentially remaining solvent traces had no significant effect on the growth of the individual fungi so the control data were pooled $(n=30)$ to calculate the reference growth rate. As no statistically significant differences were found between the duplicate extractions using a F-test, the respective data were pooled $(n=10)$ to calculate the average absolute growth rate for each fungus and solvent extract. The relative growth rates were calculated as the ratio between the reference growth rate for the individual fungi and the different solvent extracts.
Standard errors of the ratios were estimated (Kendall et al. 1994).

\section{Results and discussion}

Yields of S. sempervirens heartwood extracts

The amount of material extracted from the inner heartwood of a 17-year-old S. sempervirens tree (Tree A) grown in New Zealand with different solvents (Table 3) was in the lower range to previously published data (Table 2) but generally in accordance with it. A lower extractive content can be expected in this material as it originates from wood close to the pith from a young tree (Sherrard and Kurth 1933a). The high variability in the recorded extractive contents for individual solvents is due to a) the highly variable nature of the material (Sherrard and Kurth 1933a) and b) differences in the experimental extraction set-up among different studies (Hawley et al. 1924, Resch and Arganbright 1968, Table 3). Most matter was extracted with the polar solvents ethanol and water, while little was extracted with the non-polar solvents DCM and ethyl acetate. Less than half the amount of material from the wood is extractable directly with ethyl acetate compared with the ethyl acetate soluble fraction of the ethanol extract. This indicates that ethyl acetate soluble compounds were tightly fixed in the cell wall and a more polar solvent like ethanol is needed to swell the cell wall for their removal. Similar amounts of material were extracted from the heartwood using

Table 4 Effect of extracts from the inner five annual rings of Sequoia sempervirens heartwood (Tree A) on the growth of Gloeophyllum trabeum (Gt) and Trametes versicolor (Tv)

\begin{tabular}{|c|c|c|c|c|c|c|}
\hline Fungus & Solvent & $\begin{array}{l}\text { Absolute growth } \\
\text { rate }\left(\mathrm{mm} \mathrm{h}^{-1}\right)\end{array}$ & $\begin{array}{l}\text { Standard error of absolute } \\
\text { growth rate }\left(\mathrm{mm} \mathrm{h}^{-1}\right)\end{array}$ & $\begin{array}{l}\text { Relative growth } \\
\text { rate }^{1}(\%)\end{array}$ & $\begin{array}{l}\text { Standard error of relative } \\
\text { growth rate (\%) }\end{array}$ & $\begin{array}{l}\text { Potency }{ }^{2} \%_{\text {(activity) }} \\
\%_{\text {(extractive content) }}^{-1} \\
\end{array}$ \\
\hline \multirow[t]{7}{*}{ Gt } & Water & 0.222 & \pm 0.0055 & 80 & \pm 1.1 & 4 \\
\hline & Ethanol & 0.197 & \pm 0.0049 & 71 & \pm 1.0 & 5 \\
\hline & $\begin{array}{l}\text { Ethanol } \rightarrow \text { Ethyl } \\
\text { acetate }^{3}\end{array}$ & 0.183 & \pm 0.0024 & 65 & \pm 0.6 & 10 \\
\hline & Acetone & 0.174 & \pm 0.0025 & 62 & \pm 0.6 & 10 \\
\hline & Ethyl acetate & 0.213 & \pm 0.0049 & 76 & \pm 1.0 & 17 \\
\hline & Dichloromethane & 0.239 & \pm 0.0035 & 85 & \pm 0.8 & 25 \\
\hline & Control & 0.274 & \pm 0.0023 & & & \\
\hline \multirow[t]{7}{*}{ TV } & Water & 0.428 & \pm 0.0050 & 77 & \pm 0.7 & 4 \\
\hline & Ethanol & 0.320 & \pm 0.0107 & 58 & \pm 1.1 & 7 \\
\hline & $\begin{array}{l}\text { Ethanol } \rightarrow \text { Ethyl } \\
\text { acetate }^{3}\end{array}$ & 0.278 & \pm 0.0115 & 50 & \pm 1.1 & 14 \\
\hline & Acetone & 0.335 & \pm 0.0096 & 60 & \pm 1.0 & 11 \\
\hline & Ethyl acetate & 0.465 & \pm 0.0056 & 84 & \pm 0.8 & 11 \\
\hline & Dichloromethane & 0.569 & \pm 0.0045 & 103 & \pm 0.9 & -5 \\
\hline & Control & 0.553 & \pm 0.0040 & & & \\
\hline
\end{tabular}

${ }^{1}$ calculated as the ratio between the reference growth rate and the different solvent extract growth rates for the individual fungi.

${ }^{2}$ calculated as the relative reduction in growth rate divided by the percentage of extract from Table 3 .

${ }^{3}$ Ethanol $\rightarrow$ Ethyl acetate: ethyl acetate soluble fraction of the ethanol extract. 

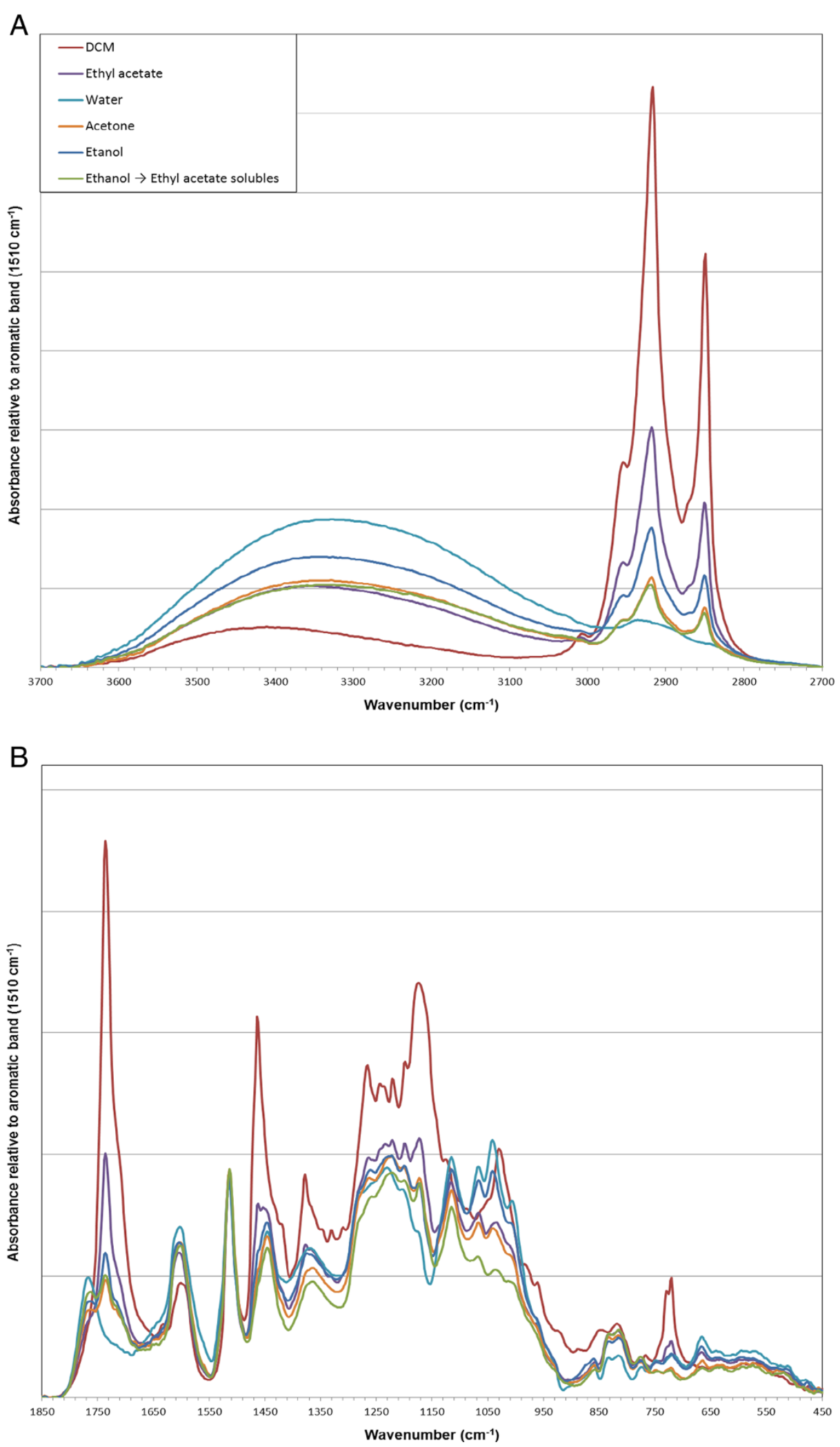

Figure 1 FT-IR spectra of extracts from the inner five annual rings of Sequoia sempervirens heartwood (Tree A) prepared using five different solvents. A: $3700-2700 \mathrm{~cm}^{-1}$ region. B: $1850-450 \mathrm{~cm}^{-1}$ region. 
acetone as obtained in the ethyl acetate soluble fraction of the ethanol extract.

\section{Bioactivity of extracts}

The bioactivity of the heartwood extracts of Tree A were assessed by the rate of growth of two test fungi, Trametes versicolor (white-rot) and Gloeophyllum trabeum (brown-rot) (Table 4). The white-rot T. versicolor grew approximately twice as fast as the brown-rot G. trabeum. However, the growth of both fungi was retarded by a similar percentage (Table 4). The DCM extract caused the least amount of growth retardation against G. trabeum but the low level of material in this extract appeared to make it the most potent. In contrast, the
DCM extract led to an increase in growth of T. versicolor. Extracts have the potential to enhance fungal growth if they contain suitable food sources. This might be the case for the DCM extract and T. versicolor. The acetone and ethanol extracts showed the highest amount of growth retardation against both species of fungi but the higher level of material in these fractions meant that their potency appeared lower than that of the DCM extract against G. trabeum. In the case of the ethanol extracts, the bioactivity was contained in its ethyl acetate soluble fraction. The ethyl acetate insoluble fraction of the ethanol extract did not show any bioactivity towards the two test fungi (data not shown). Conflicting reports on the bioactivity of $S$. sempervirens heartwood water
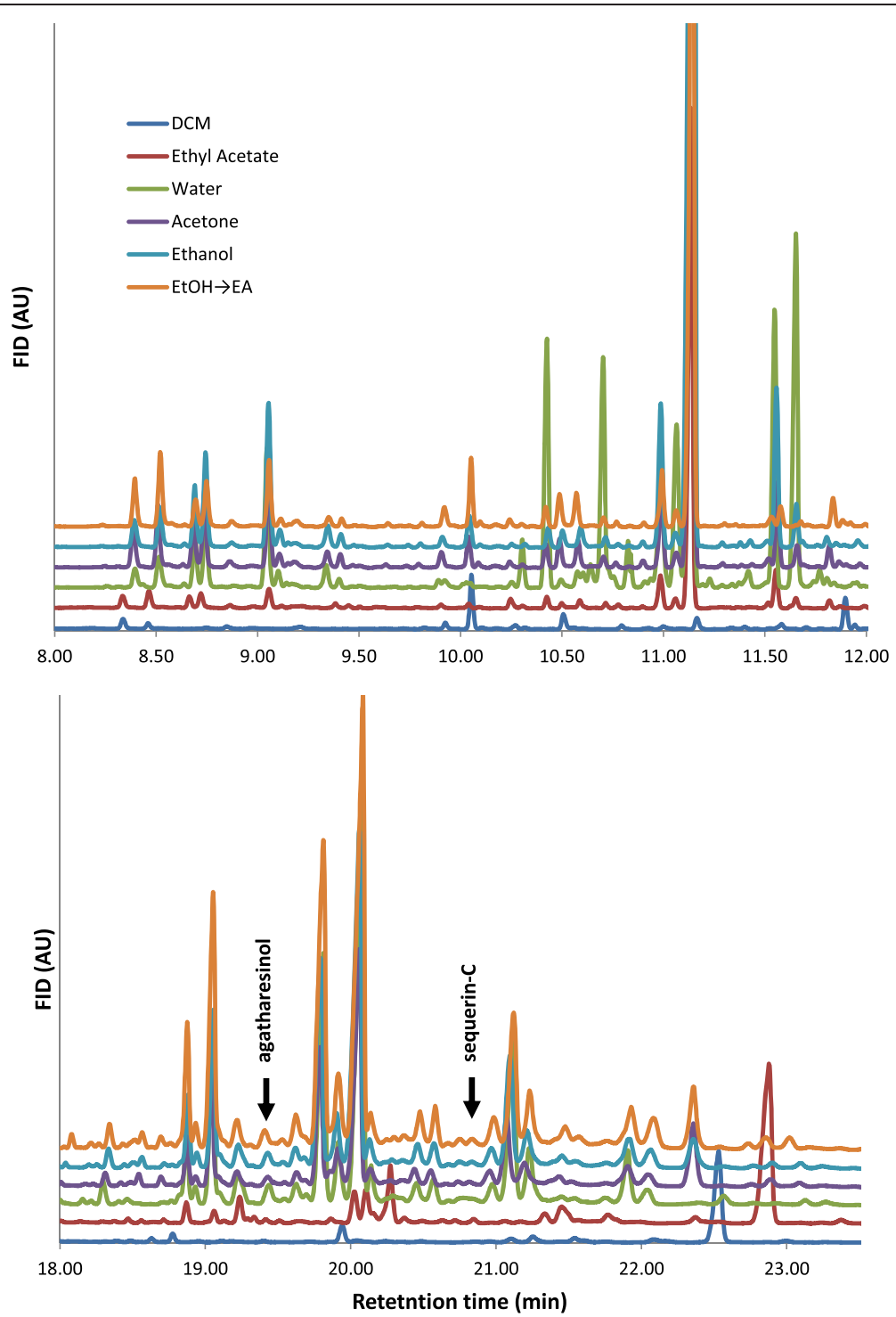

Figure 2 Gas chromatograms of TMS derivatives of extracts from the inner five annual rings of Sequoia sempervirens heartwood (Tree A) prepared using five different solvents. Top: $8-12 \mathrm{~min}$ and bottom: $18-23.5 \mathrm{~min}$. Chromatograms normalised to the peak at 11.14 min and offset; DCM extract x100. 
extracts are found in the literature. These can be attributed to the temperature at which extracts were prepared and to the species of fungi tested (Hawley et al. 1924; Sherrard and Kurth 1933a; Anderson et al. 1962). While fungicidal properties were reported against some fungi, Anderson et al. (1962) found no fungicidal activity of water extracts against G. trabeum. Additional to differences in sample preparation, it is possible that the level of active compounds was below the required threshold as the concentration of extract present in the agar was not given.

Acetone extracts were found to retard growth of both fungi tested to a similar extent as the ethanol extracts (Table 4) although they comprised only roughly half the weight (Table 3 ) so were roughly twice as potent (Table 4). This is somewhat at odds with observations by Anderson et al. (1962) who reported that acetone extraction of solid wood (in contrast to water extraction) only slightly reduced decay resistance against G. trabeum. To verify the findings of the current study, another sample from Tree A was extracted with acetone in a Soxhlet apparatus for $8 \mathrm{~h}$. The extraction liquor was collected and all the solvent evaporated (which facilitated chemical changes). The remaining solid was bioactive as it slowed the growth of G. trabeum to $76 \%$ (data not shown). This result showed that that compounds with fungicidal properties were present in acetone extracts independent of extraction method and that they are reasonably stable against chemical degradation.

Ethyl acetate extracts contained compounds capable of retarding fungal growth of both $T$. versicolor and G. trabeum (Table 4); however the inability of the solvent to swell the cell wall due to its low polarity only partially removes the active compounds. Manter et al. (2007) tested the activity of ethyl acetate extracts from $S$. sempervirens heartwood against Phytophthora ramorum (sudden oak death) but could not detect any activity.

The compounds in the ethanol extract were found to have a high contribution to the fungicidal activity of S. sempervirens heartwood (Table 4). The mass loss of solid S. sempervirens heartwood blocks after incubation with G. trabeum was reported to correlate with the amount of ethanol extractable matter (Wilcox and Piirto 1976). The bioactivity of the ethanol extract of $S$. sempervirens heartwood obtained in the current study was contained in the ethyl acetate soluble fraction (Table 4). This was consistent with the fact that the resistance of sugi (Cryptomeria japonica) against butt-rot was related to compounds in the ethylacetate-soluble fraction of ethanol heartwood extracts (Ohtani et al. 2009).

In summary, none of the extracts completely inhibited fungal growth in vitro.

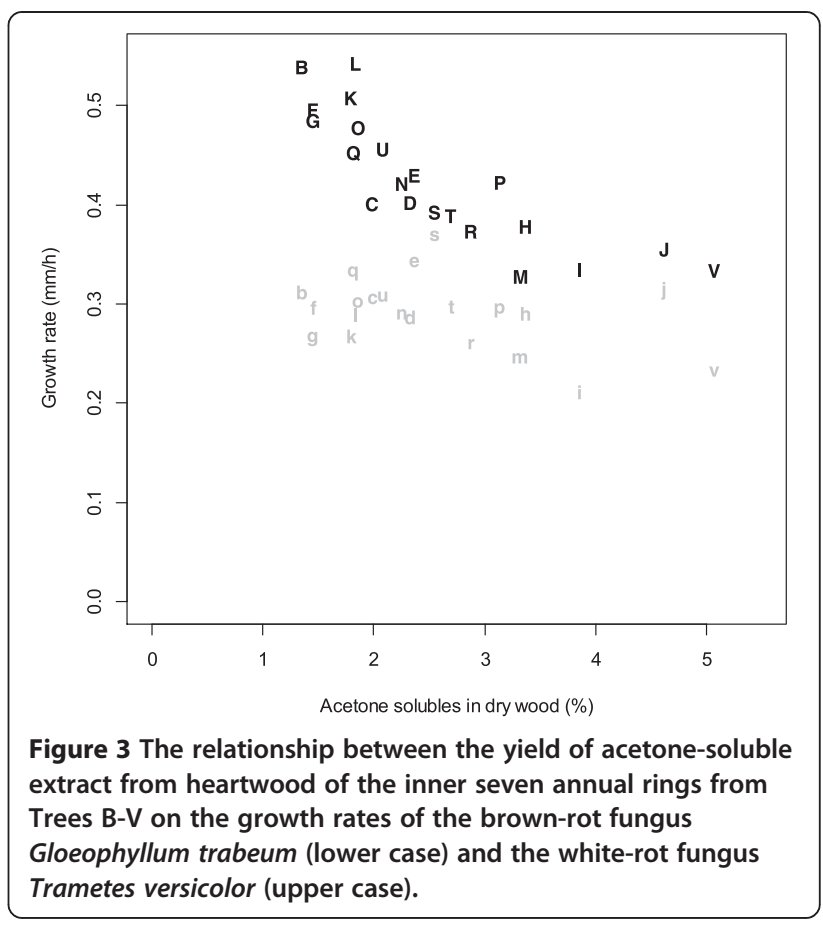

\section{Chemical features of the extracts}

Information about the chemical structure of the components of the various extracts was obtained using FT-IR spectroscopy (Figure 1). The abundance of functional groups in the extracts reflected the polarity of the solvent used for their extraction. Aliphatic groups (3000 $2800 \mathrm{~cm}^{-1}$ ) were more and hydroxyl groups (3600$3000 \mathrm{~cm}^{-1}$ ) less abundant in the extracts obtained with the non-polar solvents DCM and ethyl acetate compared to those obtained with the more polar solvents water, acetone and ethanol (Figure 1A). A qualitative difference between the water extracts and those obtained with organic solvents was observed for the signals originating from carboxyl groups $\left(1800-1700 \mathrm{~cm}^{-1}\right)$. The water extract shows only one band at $\sim 1770 \mathrm{~cm}^{-1}$ in this region while the band at $\sim 1730 \mathrm{~cm}^{-1}$ is absent (Figure 1B). A band at $\sim 1730 \mathrm{~cm}^{-1}$ was reported in Thuja plicata Donn (western red cedar) heartwood

Table 5 Effect of acetone-soluble extracts from the inner seven annual heartwood rings from Trees B-V on the growth of Gloeophyllum trabeum (Gt) and Trametes versicolor (Tv)

\begin{tabular}{lll}
\hline Fungus & $\begin{array}{l}\text { Absolute growth rate } \\
\left(\mathbf{m m ~ h}^{-1}\right)\end{array}$ & $\begin{array}{l}\text { Relative growth rate } \\
\text { (\%) }\end{array}$ \\
& $\begin{array}{l}\text { min. }- \text { max. } \\
\text { (mean in brackets) }\end{array}$ & $\begin{array}{l}\text { min. }- \text { max. } \\
\text { (mean in brackets) }\end{array}$ \\
\hline$G t$ & $0.213-0.371(0.293)$ & $65-112(89)$ \\
TV & $0.329-0.544(0.426)$ & $64-106(83)$ \\
\hline
\end{tabular}

${ }^{1}$ calculated as the ratio between the reference growth rate and the different solvent extract growth rates for the individual fungi. 
extracts and associated with $\gamma$-lactones, which are present in some lignans (e.g. originating from internal esters of plicatic acid) (Johansson et al. 2000).

Gas-chromatograms of the TMS derivatives of the water, ethanol, acetone and the ethyl-acetate-soluble fraction of the ethanol extract each contained components with the same retention times (Figure 2). However, these varied in proportion to each other. The water extract produced strong peaks at 10.45, 10.7 and $11.7 \mathrm{~min}$ that were only very weak in the other extracts. The DCM extract contained different compounds than the other extracts. Compared to the ethanol extract, the ethyl acetate soluble fraction of the ethanol extract had less material present at retention times between 8 and 12 min compared to the compounds eluting between 18 and $24 \mathrm{~min}$.

The norlignans sequerin- $C$ and agatharesinol have been associated with the natural durability of $S$. sempervirens and C. japonica heartwood (Ohtani et al. 2009; Balogh and Anderson 1965). These and several other norlignans have been identified in S. sempervirens wood (e.g. Rowe 1989). However, based on a comparison of $\mathrm{GC}$ retention times, these two compounds appeared to be present only in trace amounts in the extracts of dried S. sempervirens heartwood tested here. Norlignans have been described as unstable i.e. 'being easily oxidised to amorphous substances' and very acid sensitive and therefore cumbersome to isolate from seasoned wood (Erdtman and Harmatha 1979). This could be a reason why larger quantities of those compounds were not detected here. The low levels of sequerin- $C$ and agatharesinol could explain why characteristic FT-IR features, like a double peak $\sim 1500 \mathrm{~cm}^{-1}$, of such compounds (Balogh and Anderson 1965) were not observed in IR spectra of the extracts tested here (Figure 1).

\section{Variability of S. sempervirens heartwood extracts}

The quantity of acetone-soluble material extracted from the first seven annual rings of heartwood from Trees B-V ranged from $1.4 \%$ to $5.1 \%$ (average of $2.6 \%$ ) (Table 3 ). The amount extracted from the inner five annual heartwood rings from Tree A was within this range (3.7\%, Table 3 ). Similar varaibility was found in the bioactivity expressed as the growth rate of G. trabeum and T. versicolor on malt agar containing each acetone extract (Figure 3, Table 5). When fitting a linaer model to the data displayed in Figure 3, the amount of acetone-soluble material could explain $69 \%$ of the variation in growth rate for the white-rot $T$. versicolor while it acounted for only $16 \%$ of the variation of the growth rate for the brown-rot G. trabeum. This indicated that the fungicidal activity of the extracts was not determined only by the quantity of extractives but also the relative amounts of the numerous compounds present.
The quantity of ethanol-soluble material extracted from the inner seven annual rings of heartwood from Trees B-V ranged from $5.4 \%$ to $12.8 \%$ (average of $8.9 \%$ ) (Table 3 ). The amount extracted from heartwood less than five years old from Tree A was within this range (6.4\%, Table 3). Wilcox and Piirto (1976) found that the mass loss of solid S. sempervirens heartwood blocks after incubation with G. trabeum was correlated to the amount of ethanol-soluble material in the wood $\left(R^{2}=0.69\right)$.

\section{Conclusion}

The entire acetone-soluble extracts and ethyl-acetatesoluble fraction of the ethanol extracts caused the greatest reduction in the growth of both fungi tested. The norlignans sequerin- $C$ and agatharesinol were only present in trace amounts within the bioactive extracts of dried $S$. sempervirens heartwood, indicating that other compounds contribute to the natural durability.

Large variation in the amount of acetone-soluble material as well as the bioactivity of those extracts against the fungi G. trabeum and T. versicolor was found among 21 redwood samples. The variability of the growth rate of the fungi was only partially explained by the quantity of the acetone-soluble material. Natural durability is an essential feature of $S$. sempervirens heartwood and the large variability in extract content and in vitro antifungal activity demonstrated here has implications on the quality $S$. sempervirens timber.

\section{Competing interests}

The authors declare that they have no competing interests.

\section{Authors' contributions}

CMA conceived the study, carried out the extractions and FT-IR spectroscopy, analysed the data, participated in the assessment of the fungal assays and drafted the manuscript. NTD prepared the wood samples, established the experimental procedures, participated in the assessment of the fungal assays and contributed to the literature review. HFW conducted the GC experiments. All authors read and approved the final manuscript.

\section{Acknowledgements}

The samples were kindly provided by Wade Cornell. We would like to thank Richard Woollons (New Zealand School of Forestry) for advice regarding the statistical analysis of the data. The work was financially supported by the University of Canterbury Summer Scholarship Program.

Received: 8 May 2013 Accepted: 12 June 2014

Published online: 15 July 2014

\section{References}

Anderson, AB (1961). The influence of extractives on tree properties. 1. California redwood (Sequoia sempervirens). Journal of the Institute of Wood Science, 8, 14-34.

Anderson, AB, Duncan, CG, \& Scheffer, TC (1962). Effect of drying conditions on durability of california redwood. Forest Products Journal, 12(7), 311-312.

Anderson, AB, Ellwood, EL, Zavarin, E, \& Erickson, RW (1960). Seasoning stain of redwood lumber. Forest Products Journal, 10, 212-218.

Anderson, AB, Riffer, R, \& Wong, A (1968). Chemistry of the genus sequoia - Vl: On the cyclitols present in heartwood of Sequoia sempervirens. Phytochemistry, 7(10), 1867-1870. 
CEN. (1994). Durability of Wood and Wood-based Products - Natural Durability of Solid Wood. Part 1: Guide to the principles of testing and classification of the natural durability of wood (Vol. EN350-1, p. 11).

ASTM (2005). Standard test method of accelerated laboratory test of natural decay resistance of woods (Vol. D2017-05, p. 5).

Australian Wood Preservation Committee (2007). Protocols for assessment of wood preservatives. Clayton, Australia: . http://www.tpaa.com.au/files/AWPC\% 20protocols.pdf.

Balogh, B, \& Anderson, AB (1965). Chemistry of the genus Sequoia-II : isolation of sequirins, new phenolic compounds from the coast redwood (Sequoia sempervirens). Phytochemistry, 4(4), 569-575.

Begley, MJ, Davies, RV, Henley-Smith, P, \& Whiting, DA (1973). Constitution of sequirin-D (Sequoia sempervirens), a novel dihydronaphthalene norlignan. Journal of the Chemical Society-Chemical Communications, 18, 649-650. doi:10.1039/C39730000649.

Buchanan, MA, Lewis, HF, \& Kurth, EF (1944). Chemical nature of redwood tannin and phlobaphene. Industrial and Engineering Chemistry, 36, 907-910. doi:10.1021/ie50418a008.

Burdon, RD, Kibblewhite, RP, Walker, JCF, Megraw, RA, Evans, R, \& Cown, DJ (2004). Juvenile versus mature wood: a new concept, orthogonal to corewood versus outerwood, with special reference to Pinus radiata and P. taeda. Forest Science, 50(4), 399-415.

Cabrera, Y (2008). Improving the durability of second growth timbers of natural durable species. US: Master thesis (Wood Science), Oregon State University.

Castro, MA, Gordaliza, M, DelCorral, JMM, \& SanFeliciano, A (1996). Distribution of lignanoids in the order coniferae. Phytochemistry, 41(4), 995-1011. doi:10.1016/0031-9422(95)00512-9.

Christenhusz, MJM, Reveal, JL, Farjon, A, Gardner, MF, Mill, RR, \& Chase, MW (2011). A new classification and linear sequence of extant gymnosperms. Phytotaxa, 19, 55-70.

Clark, JW, \& Scheffer, TC (1983). Natural decay resistance of the heartwood of coast redwood Sequoia sempervirens (D-Don) Endl. Forest Products Journal, 33(5), 15-20.

Cornell, W (2002). The New Zealand Redwood Growers Handbook. Henderson, NZ: Diversified Forests Ltd.

Cown, D (2008). Redwood in New Zealand - an end-user perspective. New Zealand Journal of Forestry, 52(4), 35-41.

Cown, D, Marshall, H, Silcock, P, \& Meason, D (2013). Sawn timber grade recovery from a planted coast redwood stand growing in New Zealand. New Zealand Journal of Forestry Science, 43, 1-11.

Demaree, LA, \& Erickson, RW (1975). The temperature dependent effect of extractive content on redwood shrinkage (26th Western Dry Kiln Clubs Meeting, pp. 3-15).

Ellwood, EL, Anderson, AB, Zavarin, E, \& Erickson, RW (1960). The effect of drying conditions and certain pretreatments on seasoning stain in California redwood. Forest Science, 6(4), 315-330.

Erdtman, H, \& Harmatha, J (1979). Chemistry of the order Cupressales.58. Phenolic and Terpenoid heartwood constituents of Libocedrus-Yateensis. Phytochemistry, 18(9), 1495-1500. doi:10.1016/S0031-9422(00)98482-6.

Erdtman, H, \& Norin, T (1966). The chemistry of the order Cupressales. Fortschritte der Chemie Organischer Naturstoffe (Vienna), 24, 206-287.

Eslyn, WE, \& Highley, TL (1976). Decay resistance and susceptibility of sapwood of 15 tree species. Phytopathology, 66(8), 1010-1017.

Eslyn, WE, Highley, TL, \& Lombard, FF (1985). Longevity of untrested wood in use above ground. Forest Products Journal, 35(5), 28-35.

Farjon, A and memebers of the Conifer Specialist Group (2006). Sequoia sempervirens. www.iucnredlist.org. Accessed 06 May 2013.

Gadek, PA, Alpers, DL, Heslewood, MM, \& Quinn, CJ (2000). Relationships within Cupressaceae sensu lato: a combined morphological and molecular approach. American Journal of Botany, 87(7), 1044-1057.

Gadek, PA, \& Quinn, CJ (1989). Biflavones of Taxodiaceae. Biochemical Systematics and Ecology, 17(5), 365-372. doi:10.1016/0305-1978(89)90049-5.

Grace, JK, \& Yamamoto, RT (1994). Natural resistance of Alaska-cedar, redwood, and teak to Formosan subterranean termites. Forest Products Journal, 44(3), 41-45.

Hatam, NAR, \& Whiting, DA (1969). The constituents of Californian redwood: the constitution, absolute stereochemistry, and chemistry of sequirin-B and sequirin-C. Journal of the Chemical Society C: Organic, 14, 1921-1932.

Hawley, LF, Fleck, LC, \& Richards, CA (1924). The relation between durability and chemical composition in wood. Industrial and Engineering Chemistry, 16, 699-700. doi:10.1021/ie50175a015.
Hedley, ME, \& Foster, JB (1972). Modified soil/block technique for assessing wood decay. New Zealand Journal of Forest Science, 2(2), 287-248.

Henley-Smith, P, \& Whiting, DA (1976). New norlignans of Sequoiadendron gigantea; phytochemical comparison with Sequoia sempervirens. Phytochemistry, 15(8), 1285-1287.

Highley, TL (1995). Comparative durability of untreated wood in use above ground. International Biodeterioration \& Biodegradation, 35(4), 409-419. doi:10.1016/0964-8305(95)00063-1.

Hillis, WE (1987). Heartwood and tree exudates (Springer series in Wood science). Berlin: Springer Verlag.

Imai, T, Asai, K, Takino, M, \& Fukushima, K (2009). In vitro hydroxylation of a norlignan: from agatharesinol to sequirin $C$ and metasequirin $C$ with a microsomal preparation from Cryptomeria japonica. Phytochemistry Letters, 2(4), 196-200. doi:10.1016/j.phytol.2009.07.002.

Johansson, Cl, Saddler, JN, \& Beatson, RP (2000). Characterization of the polyphenolics related to the colour of western red cedar (Thuja plicata Donn) heartwood. Holzforschung, 54(3), 246-254. doi:10.1515/Hf.2000.042.

Johnson, GC, Thornton, JD, \& Nguyen, NK (1996). An in-ground natural durability field test of Australian timbers and exotic reference species.11. Results after more than 25 years' exposure. Material Und Organismen, 30(3), 219-230.

Jones, T, Meder, R, Low, C, O'Callahan, D, Chittenden, C, Ebdon, N, Thumm, A, Riddell, M (2011). Natural durability of the heartwood of coast redwood [Sequoia sempervirens (D.Don) Endl.] and its prediction using near infrared spectroscopy. Journal of near Infrared Spectroscopy, 19(5), 381-389. doi:10.1255/jnirs.952.

Jones, TG, Low, CB, O'Callahan, DR, \& Chittenden, CM (2014). Variation in the wood properties of coast redwood trees in New Zealand. New Zealand Journal of Forestry Science, 44, 11.

Kendall, MG, Stuart, A, Ord, JK, \& O'Hagan, A (1994). Kendall's advanced theory of statistics (6th ed.). New York: Halsted.

Kritchevsky, G, \& Anderson, AB (1955). Chemistry of the genus Sequoia. 1. The cone solid of coast redwood (Sequoia sempervirens) and giant sequoia (Sequoia gigantea). Journal of Organic Chemistry, 20(10), 1402-1406. doi:10.1021/jo01127a019.

Kuo, ML, \& Arganbright, DG (1980). Cellular-distribution of extractives in redwood and incense cedar. 1. Radial variation in cell wall extractive content. Holzforschung, 34(1), 17-22. doi:10.1515/hfsg.1980.34.1.17.

Lewis, HF, Brauns, FE, Buchanan, MA, \& Kurth, EF (1944). Chemical composition of redwood bark. Industrial and Engineering Chemistry, 36, 759-764. doi:10.1021/ ie50416a022.

MacRae, WD, \& Towers, GHN (1984). Biological-Activities of Lignans. Phytochemistry, 23(6), 1207-1220. doi:10.1016/s0031-9422(00)80428-8.

Manter, D, Kelsey, R, \& Karchesy, J (2007). Antimicrobial activity of extractable conifer heartwood compounds toward Phytophthora ramorum. Journal of Chemical Ecology, 33(11), 2133-2147. doi:10.1007/s10886-007-9368-0.

Matsushita, Y-I, Sugamoto, K, Miyakubo, K, Kurogi, C, Matsui, T, Oda, H, Fujimoto, $H$ (2008). Chemical changes in terpenes of sugi (Cryptomeria japonica) wood during steam drying in kiln at high temperature. Journal of Wood Science, 54(6), 476-482. doi:10.1007/s10086-008-0980-6.

Miller, DJ (1986). Service life of treated and untreated fence posts: 1985 Post-farm report (Research Paper, Vol. 48, p. 27). Corvallis: Forest Research Laboratory, Oregon State University.

Morrell, JJ, \& Smith, SM (1988). Fungi colonizing redwood in cooling-towers Identities and effects on wood properties. Wood and Fiber Science, 20(2), 243-249.

Ohtani, Y, Noguchi, T, \& Ichiura, H (2009). Relationship between sugi butt-rot disease and norlignans in the heartwood. Mokuzai Gakkaishi, 55(2), 92-100.

Palmer, DJ, Watt, MS, Kimberley, MO, \& Dungey, HS (2012). Predicting the spatial distribution of Sequoia sempervirens productivity in New Zealand. New Zealand Journal of Forestry Science, 42, 81-89.

Piirto, DD, \& Wilcox, WW (1981). Comparative properties of old-growth and young-growth giant sequoia of potential significance to wood utilization. University of California Division of Agricultural Sciences Bulletin, 1901, 1-26.

Resch, H, \& Arganbright, DG (1968). Variation of specific gravity, extractive content, and tracheid length in redwood trees. Forest Science, 14(2), 148-155.

Riffer, R, \& Anderson, AB (1967). Chemistry of the genus Sequoia-IV. : the structures of the C17 phenols from Sequoia sempervirens. Phytochemistry, 6(11), 1557-1562.

Rowe, JW (1989). Natural products of woody plants (Springer series in wood science). Berlin: Springer Verlag. 
Scheffer, TC, \& Eslyn, WE (1961). Effect of heat on the decay resistance of wood. Forest Products Journal, 11, 485-490.

Scheffer, TC, \& Morell, JJ (1998). Natural durability of wood: a worldwide checklist of species (Research Contribution, Vol. 22, p. 58). Corvallis: Forest Research Laboratory, Oregon State University.

Sherrard, EC, \& Kurth, EF (1933a). Distribution of extractive in redwood - its relation to durability. Industrial and Engineering Chemistry, 25, 300-302.

Sherrard, EC, \& Kurth, EF (1933b). The crystalline coloring compounds in redwood extract. Journal of the American Chemical Society, 55, 1728-1732.

Smith, LV, \& Zavarin, E (1960). Free mono- and oligo-saccharides of some Californian conifers. Tappi, 43, 218-221.

Suzuki, S, \& Umezawa, T (2007). Biosynthesis of lignans and norlignans. Journal of Wood Science, 53(4), 273-284. doi:10.1007/s10086-007-0892-x.

Takahashi, K, \& Mori, K (2006). Relationships between blacking phenomenon and norlignans of sugi (Cryptomeria japonica) heartwood III: coloration of norlignans with alkaline treatment. Journal of Wood Science, 52(2), 134-139. doi:10.1007/s10086-005-0733-8.

Tappi (1988). T 264 om-88, Preparation of wood for chemical analysis.

Taylor, AM, Gartner, BL, \& Morrell, JJ (2002). Heartwood formation and natural durability - a review. Wood and Fiber Science, 34(4), 587-611.

Walker, J (2006). Primary wood processing. Principles and practice (2nd ed.). Dordrecht: Springer.

Wilcox, WW, \& Piirto, DD (1976). Decay resistance in redwood (Sequoia sempervirens) heartwood as related to color and extractives. Wood and Fiber, $7(4), 240-245$

Yoshida, K, Nishiquchi, M, Hishiyama, S, Kato, A, \& Takahashi, K (2006). Generation and alteration of norlignans in a transition zone during the drying of a Cryptomeria japonica log. Journal of Wood Science, 52(4), 372-375. doi:10.1007/s10086-005-0777-9

Zavarin, E, \& Smith, L (1962). Processes underlying discoloration of redwood (Sequoia sempervirens) during drying and in use. Holzforschung, 16(1), 11-17. doi:10.1515/hfsg.1962.16.1.11.

Zhang, Y-M, Tan, N-H, He, M, Lu, Y, Shang, S-Q, \& Zheng, Q-T (2004). Sequosempervirin $A$, a novel spirocyclic compound from Sequoia sempervirens. Tetrahedron Letters, 45(22), 4319-4321.

Zhang, Y-M, Tan, N-H, Yang, Y-B, Lu, Y, Cao, P, \& Wu, Y-S (2005). Norlignans from Sequoia sempervirens. Chemistry \& Biodiversity, 2(4), 497-505. doi:10.1002 cbdv.200590030.

doi:10.1186/s40490-014-0017-4

Cite this article as: Davies et al.: The chemistry and bioactivity of various heartwood extracts from redwood (Sequoia sempervirens) against two species of fungi. New Zealand Journal of Forestry Science 2014 44:17.

\section{Submit your manuscript to a SpringerOpen ${ }^{\circ}$ journal and benefit from:}

- Convenient online submission

- Rigorous peer review

- Immediate publication on acceptance

- Open access: articles freely available online

- High visibility within the field

- Retaining the copyright to your article

Submit your next manuscript at $\gg$ springeropen.com 